\title{
IAMJ
}

INTERNATIONAL

AYURVEDIC

MEDICAL JOURNAL

\section{ROLE OF PIPPALYADI AGADA IN DUSHIVISHA JANYA TWAK VIKAR: A REVIEW}

\author{
Pooja Upadhyay $^{1}$, S.R. Inchulkar ${ }^{2}$, Yuvraj Kaushik ${ }^{3}$
}

${ }^{1}$ P.G. Scholar, ${ }^{2}$ Professor \& HOD, ${ }^{3}$ Lecturer,

Department of Agad Tantra Evam Vidhi Ayurved, Govt. Ayurvedic College, Raipur, Chhattisgarh, India

Corresponding Author: drpariupadhyay@gmail.com

\section{https://doi.org/ $10.46607 /$ iamj3108102020}

(Published online: October 2020)

Open Access

(C) International Ayurvedic Medical Journal, India 2020

Article Received: 04/09/2020 - Peer Reviewed: 25/10/2020 - Accepted for Publication: 27/10/2020

Check for updates

\section{ABSTRACT}

Skin is one of the important sensory organs that protects against mechanical trauma, UV light and infection, in addition the skin is concerned with thermoregulation, conservation, excretion of fluid and sensory perception. The pores present in skin help in the hair nourishment, detoxification process and keeping skin healthy. Therefore, any anatomical or physiological abnormalities in skin or related organs may leads various disorders of skin like Psoriasis, Acne, Leprosy, Hyper pigmentation, Skin allergy. The incidences of Skin diseases are increasing day by day. Modern medicine provides temporary relief but not complete cure. Therefore, peoples are gradually turning towards Ayurveda for safe and complete cure of diseases. Especially in the field of Skin diseases. In Ayurveda concept of Dushivisha is very unique. Dushivisha is a low potent poison which vitiates Dhatus. In its relationship with Raktdhatu some of the Skin diseases caused by Dushivisha which are described in Samhitas are Kustha, Visarpa, Shitpitta, Udarda, Kotha. In present era, people are exposing to various toxins in day to day life which are causing various health problems. There are many such kind of diseases where treatment does not work, as it is not eliminating the root cause. Skin diseases can be prevented and if it occurs then can be cured through Ayurvedic Agada's. Agada's are the counter measures taken against this manifestation. Achayra Yogratnakara mentioned Pippalyadi Agada in the management of Dushivisha. It can be a better choice for the treatment of Dushivisha janya Twak vikar by its Kusthghna, Krimighna, Vishaghna, Kandughna properties. 
Keyword: Pippalyadi Agada, Dushivisha, Twakvikar, Kusthghna, Skin diseases etc.

\section{INTRODUCTION}

Almost everybody suffers from Skin diseases sooner or later, and it is estimated that around $5-10 \%$ of consultations in general practice involve a skin problem. There are huge number of types of Skin diseases and dermatological expertise can be achieved only by prolonged clinical experience. ${ }^{1}$ Now a days due to uses of various synthetic and chemical added food items and changes in the lifestyle of a modern man, immune system of a person declines and leads to evolution of various diseases. Skin diseases are common among them.

\section{The Histology of Normal Skin}

According to Modern ${ }^{2}$ - Skin has layers, the epidermis and dermis. Coned shaped dermal papillae extend upward into the epidermis forming peg like rete ridges. Various layers of the epidermis from below upwards are Stratum Germinatum, Stratum Malpighi, Stratum Sgranulosum, Stratum Indicum (palms and soles) and Stratum Corneum. The dermis has fibrocollagenic tissue containing blood vessels, lymphatics and nerves and adnexal structures (sweat glands, sebaceous glands, hair follicles, arrectores pilorum and nails).

According to Ayurveda ${ }^{3}$ - The seven layers of skin are formed in the same manner as the layers of cream are formed on the surface of boiled milk.

* The first layer from outside is known as Avabhasini (reflecting layer). This reflects all the colours and the five shades (five bhutas) are brought into light. Its thickness one-eighteenth of the vrihi (rice grain) and this layer is the seat of Shidma and Padma-kantaka.

* The second layer is called Lohita (reddish layer), its thickness one-sixteenth of the vrihi and this layer is the seat of Tilkalaka, Nyaccha, Vyainga.

* The third layer is called Shweta (white layer), its thickness one-twelfth of the vrihi and this layer is the seat of Charmadal, Ajagalli and Mashaka.

* The fourth layer is called Tamra (pigment layer), its thickness one- eighth of the vrihi and this layer is the seat of Kilasa, Kustha.
* The fifth layer is called Vedini (sensory layer), its thickness one-fifth of the Vrihi and this layer is the seat of Kustha, Visarpa.

* The sixth layer is called Rohini (proliferating layer), its thickness of this equal to the vrihi and this layer is the seat of Granthi, Apachi, Arbuda, Slipada and Galganda.

* The seventh layer is called Mansadhara (muscle supporting layer), it has twice the thickness of vrihi and this layer is the seat of Bhagandara, Vidradhi and Arsha.

Aetiology of Twak Vikar- In Ayurveda etiology of Skin diseases given are consumption of contradictory diets, eating again before the previous meal has been digested, incompatible food, suppressing the natural urges, unsystematic employment of procedures of oleation, cause diseases of the skin.

Definition of Dushivisha - Dushivisha is one of the unique concepts explained in Ayurveda. It is a type of toxin which remains inside the body for long-term \& then produces various ill effects on the body. Sthavar, Jangam or Kritirima visha which cannot be eliminated from the body completely but it is destroyed or denatured due to use of anti poisonous remedies in past , fire, air, sun exposure or due to its low potency it does not kill the human instantly. But as it is encapsulated by Kapha dosha it remains accumulated in the body for several years producing various ill effects. ${ }^{4}$ Different factors aggravates this condition, like, Dushta desha (wet lands), Dushta Kaal (cloudy days), Dushta anna, Diwaswapna (day sleep), Pragwat (air from eastern region), Ajirna (Indigestion), Ativyayam (over exertion), Ativyavay (sexual intercourse), Krodha (anger) ${ }^{5,6,7}$ In present era, people are exposing to various toxins in day to day life which is causing various health problems. There are many such illnesses where treatment does not work, as it is not eliminating the root cause.

Purva Roopa of Dushivisha Poisoning - According to Sushruta - Nidra (Sleepiness), Gurutva (Heaviness), Jrumbha (Yawning), Vishlesh (Sense of looseness in 
joints), Romancha (Horripilation), Angamarda (Bodyache). ${ }^{8}$

Rupa of Dushivisha Poisoning - According to Sushruta, clinical features of Dushivisha are as follows intoxication, fainting and discoloration, intermittent fever, oligospermia, urticaria, vomiting, epileptic attacks, increased thirst, Appearance of red patches all over the body, indigestion, diarrhoea, insanity, distension of the abdomen, Oedema of the face and extremities, Skin disorders. ${ }^{9}$ Dushivisha vitiates Rakta dhatu and causes skin lesions such as Kitibha and Kotha. Dushivisha vitiates the Doshas and Dhatus one by one and at last results in death. Some of the poisons produces insanity some of them cause constipation, some of cause loss of semen, while others lead to blurred speech, leprosy (kustha) and various other diseases. ${ }^{10}$ Complications like pyrexia, burning sensation, hiccough, obstipation, azospermia, oedema, diarrhoea, fainting, heart disease, abdominal enlargement, insanity, tremor and other complications may develop. ${ }^{11}$

\section{Aim and Objectives-}

1. To study about Dushivisha.

2. To study about Pippalyadi Agada.

3. To understand effect of Pippalyadi Agada in Dushivisha janya Twak vikar.
Material and Method - This paper is based on textbook of Ayurveda along with Modern textbooks and various websites to collect information on the relevant topics.

Management - According to Acharyas Twak vikar as Kitibha, Kotha, Kandu are mentioned in the sign and symptoms of Dushivisha. The etio-pathogenesis of dermatological disorder involves the Sapta dhatu, Vata, Pitta, Kapha, Twacha, Rakta, Mansa and Ambu / Lasika, which is vitiated by different sources of Dushivisha. So, on looking at the importance of skin and increased incidence rate of Skin diseases, it's a need to find some conservative source which would be helpful in management of Skin diseases from the root by cleansing vitiated Dhosha and balancing whole body. These diseases can be prevented and if it occurs then can be cured through Ayurvedic Agada's. Agada's are the counter measures taken against this manifestation. Dushivisha janya Twak vikar may be cured by Pippalyadi Agada described in Yogratnakara in the treatment of Dushivisha.

Pippalyadi Agada ${ }^{\mathbf{1 2}}$ - Pippalyadi Agada includes nine drugs Pippali, Dhanyaka, Jatamansi, Lodhra, Ela, Maricha, Tagara, Sarjika kshara, Suvarn gairika.

Table 1: Contents of Pippalyadi Agada

\begin{tabular}{|l|l|l|}
\hline Drug (Sanskrit Name ) & Latin name & Family \\
\hline Pippali $^{13}$ & Piper Longum Linn. & Piperaceae \\
\hline Dhanyaka $^{14}$ & Coriandrum Sativum Linn & Umbelliferae \\
\hline Jatamansi $^{15}$ & Nardostachys Jatamansi DC & Valerianaceae \\
\hline Lodhra $^{16}$ & Symplocos Racemosa Roxb. & Symplocaceae \\
\hline Sukhsma ela $^{17}$ & Elleteria Cardimomum (Linn.) Maton & Zingiberaceae \\
\hline Maricha $^{18}$ & Piper Nigrum Linn. & Piperaceae \\
\hline Tagara $^{19}$ & Valeriana Wallichii DC. & Valerianaceae \\
\hline${\text { Badi } \text { ela }^{20}}_{\text {Sarjika } \text { kshara }^{21}}$ & Amomum Subulatum Roxb. & Zingiberaceae \\
\hline Suvarna gairika $^{22}$ & & \\
\hline
\end{tabular}

Table 2: Ras Panchaka (Guna - Karma) of Pippalyadi Agada

\begin{tabular}{|l|l|l|l|l|l|l|}
\hline $\begin{array}{l}\text { Drug (Sanskrit } \\
\text { Name) }\end{array}$ & Rasa & Guna & Veerya & Vipaka & Doshghnta & Therapeutic Uses \\
\hline Pippali $^{13}$ & Katu & $\begin{array}{l}\text { Laghu } \\
\text { Snigdha Tik- } \\
\text { shna }\end{array}$ & $\begin{array}{l}\text { Anushna } \\
\text { sheeta }\end{array}$ & Madhura & Kaphavatashamaka & $\begin{array}{l}\text { Kusthaghna } \\
\text { Krimighna } \\
\text { Raktavikar }\end{array}$ \\
\hline
\end{tabular}




\begin{tabular}{|c|c|c|c|c|c|c|}
\hline & & & & & & $\begin{array}{l}\text { Deepan } \\
\text { Shothaghan }\end{array}$ \\
\hline Dhanyaka ${ }^{14}$ & $\begin{array}{l}\text { Kashaya } \\
\text { Tikta } \\
\text { Katu } \\
\text { Madhura }\end{array}$ & $\begin{array}{l}\text { Laghu } \\
\text { Snigdha }\end{array}$ & Ushna & Madhura & Tridoshashamaka & $\begin{array}{l}\text { Deepan } \\
\text { Pachan } \\
\text { Krimighna, } \\
\text { Visarpa } \\
\text { Sothaghana } \\
\text { Agnimandyahar Daha- } \\
\text { nasak }\end{array}$ \\
\hline Jatamansi $i^{15}$ & $\begin{array}{l}\text { Tikta } \\
\text { Kashaya } \\
\text { Madhura }\end{array}$ & $\begin{array}{l}\text { Laghu } \\
\text { Snigdha }\end{array}$ & Sheeta & Katu & Tridoshashamaka & $\begin{array}{l}\text { Twakvikar Varnya } \\
\text { Kusthaghna Shothaghna } \\
\text { Vishavikar } \\
\text { Dahanasak Deepan, Pa- } \\
\text { chan }\end{array}$ \\
\hline Lodhra ${ }^{16}$ & Kashaya & Laghu ruksha & Sheeta & Katu & $\begin{array}{l}\text { Kapha- } \\
\text { pittashamaka }\end{array}$ & $\begin{array}{l}\text { Raktavikar Twakvikar } \\
\text { Sothahara } \\
\text { Kusthaghna } \\
\text { Vishagha } \\
\text { Vranaropana }\end{array}$ \\
\hline Suksma-ela ${ }^{17}$ & $\begin{array}{l}\text { Katu } M a- \\
\text { dura }\end{array}$ & $\begin{array}{l}\text { Laghu } \\
\text { Ruksha }\end{array}$ & Sheeta & Katu & $\begin{array}{l}\text { Kapha- } \\
\text { vatashamaka }\end{array}$ & $\begin{array}{l}\text { Deepan } \\
\text { Pachan }\end{array}$ \\
\hline Maricha ${ }^{18}$ & Katu & $\begin{array}{l}\text { Laghu } \\
\text { Ruksha } \\
\text { Teekshana }\end{array}$ & Ushna & Katu & $\begin{array}{l}\text { Kapha- } \\
\text { vatashamaka }\end{array}$ & $\begin{array}{l}\text { Switra Kilasa, Pama, } \\
\text { Krimighna Twakvikar, } \\
\text { Agnimandya }\end{array}$ \\
\hline Tagara $^{19}$ & $\begin{array}{l}\text { Tikta } \\
\text { Katu } \\
\text { Kashaya }\end{array}$ & $\begin{array}{l}\text { Laghu } \\
\text { Snigdha }\end{array}$ & Ushna & Katu & $\begin{array}{l}\text { Kapha- } \\
\text { vatashamaka }\end{array}$ & $\begin{array}{lr}\text { Vishaghna } & \text { Kusthaghna } \\
\text { Varyna } & \text { Raktavikar } \\
\text { Vranaropana } & \\
\text { Deepan } & \\
\text { Visarpa } & \end{array}$ \\
\hline Badi ela ${ }^{20}$ & $\begin{array}{l}\text { Tikta } \\
\text { Katu }\end{array}$ & $\begin{array}{l}\text { Laghu } \\
\text { Ruksha }\end{array}$ & Ushna & Katu & Kapa-vata shamaka & $\begin{array}{l}\text { Deepan } \\
\text { Kandughna Raktavikara } \\
\text { Twakaroga Vrana }\end{array}$ \\
\hline Sarjika kshara ${ }^{21}$ & $\begin{array}{l}\text { Snigdha } \\
\text { Sheeta }\end{array}$ & & & & & Krimighna \\
\hline $\begin{array}{l}\text { Suvarna gairi- } \\
k^{22}\end{array}$ & $\begin{array}{l}\text { Ruksha } \\
\text { Teekshana } \\
\text { Laghu } \\
\text { Ushna }\end{array}$ & & & & & $\begin{array}{l}\text { Vishaghna } \\
\text { Kandughna } \\
\text { Udarda }\end{array}$ \\
\hline
\end{tabular}

\section{DISCUSSION}

Mode of action of Pippalyadi Agada can be explained in following way: Drugs exhibiting quick control over vitiating Vata and Kapha, while permanent relief is attainable through implementation of drugs having action Agni and Pittastana along with Vatakaphaghnata. So, the drug administered for the treatment of Dushivisha janya Twak vikar (skin disorder) should have action on Pitta. Pippalyadi Agada has used as Vishaghna (Antitoxic) in Dushivisha janya Twak vikar (skin disorders). In all Twak Rogas mostly Raktadushti is the major factor. All the contents in Pippalyadi Agada have Vishaghna, Kusthghna and Rakta-vikarnasak properties and also some of the drugs in these Agada like Pippali, Jatamansi, Lodhra, Ela, Tagar, are Kushthaghna, Vishaghna, 
Vranaropana, Sothaghana mostly act on Twakroga. The Deepan, Pachan properties of these drugs acts on Dushivisha treatment. The Kustha manifest by krimi and Pippali, Dhanyaka, Maricha has Krimighna property. Lodhra is the single drug of choice in skin diseases. The Kshara itself having the property to destroy the degenerated Dhatus and remove unhealthy tissues and Doshas from their location. The goals of treatment are eliminating the toxins and prevent skin diseases along with prevention of scar. Modern medications for Skin disorders include topical therapies, antimicrobials, hormones, surgery, UV- radiations, laser treatment etc. But these have many limitations and adverse effects. Pippalyadi Agada may be play a good role in the management of Skin diseases by the action of neutralize the toxins in body and purifying the blood by its Vishaghna property. The drugs having Kusthaghna, Krimighna, Sothahara, Kandughna properties, which are beneficial for the Skin diseases. Vranaropana property promotes faster healing of lesions without leaving scars. Rakta shodhaka property is helpful in blood purification. The Kshara itself having the property to destroy the degenerated Dhatus and remove unhealthy tissues and Doshas from their location and thus prevent from chronic diseases by cleaning the body internally and are helpful in management of Dushivisha janya Twak vikar. Thus, this Pippalyadi Agada may be cures the Dushivisha janya Twak vikar.

\section{CONCLUSION}

Skin disorders require long-term management. Today's changed lifestyle like Irregular diet, Pollution, Stress, Hormonal changes are directly affecting the skin and causes many Skin diseases. As we see the prevalence rate increases, so there is scope for new researches \& study. Any type of poison Dushivisha and Gara Visha produced in body due to Agnimandya, Virudha-Aahara, which are not properly expelled out of body. Dushivisha vitiates the dhatus, causing hypersensitivity reaction in skin and leads to Skin disorders. Conclude that Dushivisha is important causative factor of Twak Vikar (Skin disorders). The Virudhaahara, Ajirna, Agnimandya, Vegavrodha and Mansik bhava are causes of Dushivisha. So Pippalyadi Agada is beneficial for Dushivisha janya Twak vikar, by its action and properties. It will be helpful to eliminate Dushivisha from body and to cure the dermatological symptoms. Hence these review studies are concluded from this discussion, that Pippalyadi Agada may be effective in Dushivisha janya Twak vikar.

\section{REFERENCES}

1. Dr. S. Suresh babu, The principles and practise of Kayachikitsa volume-2 Chaukhambha Orientalia p403.

2. Harsh Mohan, Textbook of pathology reprint edition seventh Jaypee brothers' medical publishers (P) Ltd. Kathmandu Nepal 2015 p-760.

3. Prof. G.D. Singhal \& colleagues, Shusruta samhita ancient Indian surgery part-2 Chaukhamba Sanskrit Pratishthan Delhi p- 35-36.

4. Kaviraj Ambikadutta Shastri, Sushrut Samhita of Maharshi-Sushruta edited with Ayurved Tattva Sandipika Forwarded by Dr. Pranajivana Manekchanda Mehta Part I Kalpasthan Chaukhaba Sanskrit sansthan, Fourteenth edition 2003 p- 25.

5. Kaviraj Ambikadutta Shastri, Sushrut Samhita of Maharshi-Sushruta edited with Ayurved Tattva Sandipika Forwarded by Dr. Pranajivana Manekchanda Mehta Part I Kalpasthan Chaukhaba Sanskrit sansthan, Fourteenth edition 2003 p-26.

6. Dr Ganesg Krushna Garde, Sartha Vagbhat Uttarsthana Anmol Prakashan Pune Reprint edition 2006 p- 460 .

7. Vaidya Jadavji Trikamji, Sushrut Samhita of Sushruta with Niandhasangraha commentary of Shri Dalhanacharya edited by Acharya \& Narayan Ram Acharya Kavyatirtha Kalpasthan Reprint edition Chaukhaba Sanskrit sansthan 2010 p- 566.

8. Kaviraj Ambikadutta Shastri, Sushrut Samhita of Maharshi-Sushruta edited with Ayurved Tattva Sandipika Forwarded by Dr. Pranajivana Manekchanda Mehta Part I Kalpasthan Chaukhaba Sanskrit sansthan, Fourteenth edition 2003 p-26.

9. Vaidya Yadavaji Trikamji, Sushruta Samhita of Sushruta with the Nibandhasangraha commentary of Shri Dalhanacharya, edition Varanasi Chaukhamba Surabharati Prakashan 2012 p-566.

10. Ambika Datta Shastri Susruta Samhita Ayurved Tattva Sandipika Hindi Commentary Kalp (2/32) Varanasi Chaukhambha Sansakrit Sansthan 2009 p-33. 
11. G.D. Singhal, Toxicological Consideration in Ancient Indian Surgery Vol-III First edition p- 48.

12. Vaidya Shrilaxmipati Shastri, Yogratnakar vidyotani hindi tika Varanasi Chaukhamba Prakashan p- 470471.

13. The Ayurvedic Pharmacopoeia of India, Government of India, ministry of health \& family welfare department of ISM\&H, part -1 vol-IV first edition 2005 p91.

14. The Ayurvedic Pharmacopoeia of India, Government of India, ministry of health \& family welfare department of ISM\&H, part -1 Vol-I first edition 2005 p- 41.

15. The Ayurvedic Pharmacopoeia of India, Government of India, ministry of health \& family welfare department of ISM\&H, part -1 Vol-I first edition 2005 p- 67.

16. The Ayurvedic Pharmacopoeia of India, Government of India, ministry of health \& family welfare department of ISM\&H, part -1 Vol-I first edition 2005 p- 82.

17. The Ayurvedic Pharmacopoeia of India, Government of India, ministry of health \& family welfare department of ISM\&H, part -1 Vol-I first edition 2005 p101.

18. The Ayurvedic Pharmacopoeia of India, Government of India, ministry of health \& family welfare department of ISM\&H, part -1 Vol-III first edition 2007 p115.

19. The Ayurvedic Pharmacopoeia of India, Government of India, ministry of health $\&$ family welfare department of ISM\&H, part -1 Vol-I first edition 2005 p146.

20. The Ayurvedic Pharmacopoeia of India, Government of India, ministry of health \& family welfare department of ISM\&H, part -1 Vol-VI first edition 2008 p165.

21. Pt. Kashinath Shastrina, Rastarangni pranacharya shri Sadanand sharmana virchita, trayodashtarang reprint edition Motilal banarsidas Delhi, 2012 p-314.

22. The Ayurvedic Pharmacopoeia of India, Government of India, ministry of health \& family welfare department of ISM\&H, part -1 Vol-VII first edition 2008 p5.

\section{Source of Support: Nil \\ Conflict of Interest: None Declared}

How to cite this URL: Pooja Upadhyay et al: Role Of Pippalyadi Agada In Dushivisha Janya Twak Vikar: A Review. International Ayurvedic Medical Journal \{online\} 2020 \{cited October, 2020\} Available from: http://www.iamj.in/posts/images/upload/4772_4777.pdf 